JKM (Jurnal Kebidanan Malahayati),Vol 7,No.2.April 2021,

ISSN (Print) 2476-8944 ISSN (Online) 2579-762X, Hal 265-271

\title{
PEMBERIAN EKSTRAK DAUN KATUK TERHADAP KELANCARAN ASI PADA IBU MENYUSUI
}

\author{
Rosdianah $^{1 *}$, Irmawati S ${ }^{2}$ \\ 1,2Program Studi DIV Kebidanan, Universitas Megarezky Makassar, Sulawesi Selatan, Indonesia \\ *Korespondensi email: nana.aswan15@gmail.com
}

\section{ABSTRACT: GIVING KATUK LEAF EXTRACT AGAINST THE SMOOTHNESS OF BREAST MILK IN NURSING MOTHERS}

Background: Exclusive breast milk coverage in Indonesia is only 38\%, has not reached the expected figure of $80 \%$. The low coverage of Exclusive breast milk is influenced by the cessation of breastfeeding for infants due to the lack of breast milk production. One of the efforts that can be done to launch the production of breast milk is by consuming katuk leaf extract.

Purpose: Knowing the effect of katuk leaf extract on the smoothness of breast milk in nursing mothers who have babies aged 0-6 months in the Working Area of the Kassi-Kassi Health Center in Makassar City in 2020.

Methods: This type of research uses Quasi-experiments with the design of Non-Equivalent Control Group Design. The number of samples of 30 people divided into two groups, namely control and intervention, based on inclusion and exclusion criteria that have been determined. The intervention group was given katuk leaf extract at a dose of $2 \times 200 \mathrm{mg}$ for 15 days and will be seen the effect on day 15 while the control group is not given intervention. Data analysis used in research is univariate analysis with independent $t$-test.

Result: Based on independent sample t-test results, obtained $p$-value $0.009<\alpha(0.05)$, then $\mathrm{H} 0$ rejected and $\mathrm{Ha}$ received. This indicates that katuk leaf extract has an influence on the production of breast milk.

Conclusion: There is an effect of katuk leaf extract on the smoothness of breast milk in mothers who have babies aged 0-6 months. So that katuk leaf extract can be recommended for mothers who have problems in breastfeeding. In the selection of safe katuk leaf extract should pay attention to the side effects of the drug and have permission from the Food and Drug Administration (BPOM).

Suggestion_It is hoped that health workers will conduct socialization in the community about the effectiveness of katuk leaf simplicia on breast milk production in infants. Health workers need to monitor the accuracy of the dose / dose, the timeliness of use, the accuracy of how to use it, and the accuracy of choosing ingredients correctly. So as to produce traditional medicine in the form of katuk leaf simplicia.

Keywords: Katuk Leaf Extract, Breastfeeding Mother, Smooth breast milk

\section{ABSTRAK}

Latar Belakang: Cakupan ASI Eksklusif di Indonesia hanya sebesar 38\%, belum mencapai angka yang diharapkan yaitu $80 \%$. Rendahnya cakupan ASI Eksklusif dipengaruhi oleh adanya penghentian pemberian ASI bagi bayi dengan alasan karena produksi ASI yang masih kurang. Salah satu usaha yang dapat dilakukan untuk melancarkan produksi ASI yaitu dengan mengkonsumsi ekstrak daun katuk.

Tujaun: Mengetahui pengaruh pemberian ekstrak daun katuk terhadap kelancaran ASI pada ibu menyusui yang memiliki bayi usia 0-6 bulan di Wilayah Kerja Puskesmas Kassi-Kassi Kota Makassar Tahun 2020.

Metode: Jenis penelitian menggunakan Quasi eksperimen dengan rancangan Non Equivalent Control Group Design. Jumlah sampel sebanyak 30 orang yang dibagi dalam 2 kelompok yaitu control dan intervensi berdasarkan kriteria inklusi dan eksklusi yang telah ditetapkan. Kelompok intervensi diberikan ekstrak daun katuk dengan dosis $2 \times 200 \mathrm{mg}$ selama 15 hari dan akan dilihat efek pada hari ke 15 sedangkan untuk kelompok control tidak diberikan intervensi. Analisis data yaitu analisis univariat menggunakan uji independent t-test.

Hasil: Berdasarkan hasil uji independent sample t test didapatkan nilai $p$-value $0,009<a(0,05)$, maka $\mathrm{H}_{0}$ ditolak dan $\mathrm{H}_{\mathrm{a}}$ diterima. Hal ini menunjukkan bahwa ekstrak daun katuk memberikan pengaruh terhadap pengeluaran Air Susu Ibu.

Simpulan: Ada pengaruh pemberian ekstrak daun katuk terhadap kelancaran ASI pada ibu yang memiliki bayi usia $0-6$ bulan. Sehingga ekstrak daun katuk dapat direkomendasikan bagi ibu yang memiliki kendala dalam menyusui. Dalam pemilihan ekstrak daun katuk yang aman harus memperhatikan efek samping dari obat dan telah memiliki ijin dari Badan Pengawas Obat dan Makanan (BPOM). 


\section{Rosdianah, Irmawati S}

Saran Diharapkan kepada petugas kesehatan agar melakukan sosialisasi di masyarakat tentang efektifitas simplisia daun katuk terhadap produksi ASI pada bayi. Tenaga kesehatan perlu mengawasi ketepatan takaran/dosis, ketepatan waktu penggunaan, ketepatan cara penggunaan, dan ketepatan pemilihan bahan secara benar. Sehingga menghasilkan obat tradisional berupa simplisia daun katuk.

Kata Kunci : Ekstrak Daun Katuk, Ibu Menyusui, Kelancaran ASI

\section{PENDAHULUAN}

Air Susu Ibu (ASI) mengandung banyajk nutrisi dan zat antibody untuk melindungi bayi dari infeksi karena mudah dicerna dan diserap yang bermanfaat bagi pertumbuhan dan perkembangan yang optimal bagi bayi, bahkan manfaat dari ASI telah banyak dibuktikan oleh para penerliti (American Academy of Pediatrics, 2012; Ballard and Morrow, 2013; Mirzaie et al., 2018; Aliya et al., 2020).

Dalam resolusi World Health Assembly (WHA) tahun 2001 dikatakan bahwa bayi berhak memperoleh ASI Eksklusif sejak lahir sampai usia 6 bulan, setelah itu dapat diberikan makanan pendamping ASI (MP-ASI). Pemberian ASI sampai 6 bulan secara eksklusif dilanjutkan sampai 2 tahun pertama kehidupan dapat mencegah $13 \%$ dari 10 juta kematian setiap tahun (Ballard and Morrow, 2013; Andreas, Kampmann and Mehring Le-Doare, 2015)

Menurut World Health Organization (WH0,2016), rata-rata pemberian ASI eksklusif didunia yaitu $36 \%$ pada periode $2000-2014$ (WHO, 2017). Sedangkan data Profil Kesehatan Indonesia pada tahun 2016, cakupan pemberian ASI Eksklusif pada bayi $0-6$ bulan mencapai $54,3 \%$, dan pada tahun 2017 mencapai 55,7\%. Meskipun terjadi peningkatan tetapi capaian ASI Eksklusif di Indonesia belum mencapai angka yang diharapkan yaitu sebesar 80\% (KEMENKES, 2018). Data Dinas Kesehatan Kota Makassar Tahun 2017 cakupan ASI Eksklusif pada usia 0-6 bulan sebesar 67,80\% sedangkan pada tahun 2018 menglami penurunan yaitu 65,75\% (Dinas Kesehatan Kota Makassar, 2019).

Masih rendahnya cakupan ASI Eksklusif menunjukkan bahwa tidak banyak ibu yang berhasil dalam pemberian ASI kepada bayinya. Salah satu factor yang mempengaruhi yaitu adanya penghentian pemberian ASI kepada bayi dengan alasan produksi ASI kurang (Fikawati and Syafiq, 2009; Jannah, 2016; La Aga and Alifariki, 2019). Penelitian membuktikan adanya presepsi dari ibu terkait ASI tidak cukup merupakan salah factor penghambat pemberian ASI eksklusif (Fikawati and Syafiq, 2009; Hirani and Karmaliani, 2013; Prabasiwi, Fikawati and Syafiq, 2015). Dalam praktiknya , menyusui tidak semudah yang dibayangkan, namun tidak sesulit yang dikira. Menyusui tidak hanya membutuhkan gizi cukup dan kesehatan yang prima tetapi juga membutuhkan tekad dan keyakinan bahwa ibu akan sukses dalam upayanya memberikan makanan terbaik, yaitu ASI. Saat ibu sudah mantap dengan keputusannya untuk memberikan ASI eksklusif, ada saja hambatan yang harus dihadapi yang tidak jarang justru membuat ibu ragu, ketakutan, sedih, dan merasa tidak mampu memberikan ASI (Subratha, 2020).

Untuk menjaga kualitas ASI, ibu harus mengikuti pola makan dengan prinsip gizi seimbang dan mengkonsumsi beragam makanan, terutama sayuran berwarna hijau tua yang baik untuk melancarkan ASI (Saskiyanto Manggabarani, Anto Jamma Hadi and Bunga, 2018). Salah satu tumbuh yang secara tradisional dipakai untuk memperbanyak dan melancarkan ASI adalah daun katuk (Sauropus androgynous (L.) Merr, kandungan kalori, protein, dan karbohidrat daun katuk hampir setara (Suwanti and K. Kuswati, 2016). Bahkan kandungan zat besi daun katuk lebih unggul dari pada daun pepaya dan daun singkong. Selain itu, juga kaya vitamin A, B1 dan C. Disamping kaya protein, lemak, vitamin, dan mineral, daun katuk juga memiliki kandungan tanin, saponin, dan alkaloid papaverin (Suryaningsih, 2009; Rahmanisa and Aulianova, 2016; Herawati and Desriyeni, 2017).

Penggunaan daun katuk telah banyak diteliti dengan pemakaian dibuat sayur dan dilalap (Aulianova, 2016). Namun mengkonsumsi daun katuk dalam bentuk sayur atau lalap tidak praktis apalagi untuk masyarakat perkotaan karena kesulitan untuk mendapatkan bahan segar setiap saat dan kurang baik jika air rebusan harus di simpan lama dalam tempat penyimpanan (Sa'roni Sa'roni, Tonny Sadjiman, Mochammad Sja'bani, 2004). Kemudian penelitian yang dilakukan Suwanti, Endang dan Kuswati (2016) menyebutkan bahwa mengkonsumsi daun katuk yang berlebihan dapat menyebabkan efek samping keracunan paperina bila dikonsumsi mentah yang dapat mengakibatkan sumbatan udara di paru-paru sampai kematian (Suwanti and Kuswati, 2016). 


\section{JKM (Jurnal Kebidanan Malahayati),Vol 7,No.2.April 2021, \\ ISSN (Print) 2476-8944 ISSN (Online) 2579-762X, Hal 265-271}

Uji toksisitas yang dilakukan oleh Lucia, E.W., Dayang., E.M. dan Widayati, S. (1997) dengan menguji toksisitas akut dan teratogenik pada mencit menunjukkan bahwa daun katuk tidak mengadung toksik yang dapat menimbulkan kecacatan pada janin (S, M and E., 2012). Temuan Ini sejalan dengan penelitian yang dilakukan Ridho, Islami (2018) dengan menguji Toksisitas Subkronis Singkat Oral Sup Daun Katuk (Sauropus androgynous) Pada Tikus Wistar Betina menunjukkan pada daun katuk tidak ada efek toksik sehingga penggunaannya masih relatif aman jika dikomsumsi selama kurang dari 30 hari (Islamie, 2018).

Untuk mengatasi permasalahan tersebut dibuat sediaan dalam bentuk kapsul siap minum yang mengandung $100 \%$ ekstrak daun hijau yang diproses secara alami dan higienis tanpa tambahan bahan apapun dan tetap menjaga khasiat daun katuk. Tanpa efek samping apapun sehingga kapsul daun katuk aman dikonsumsi untuk ibu dalam masa menyusui dan penyembuhan beberapa penyakit. Manfaat ekstrak daun katuk mengobati penyakit kulit, mengatasi sembelit, menyembuhkan luka, mengobati susah BAK, meningkatkan vitalitasi seksual pria, meredakan dan menurunkan demam (Suryaningsih, 2009; Aulianova, 2016; Tri Mulyani et al., 2017).

Dari studi pendahuluan yang telah dilakukan di Puskesmas Kassi-Kassi Kota Makassar dari 6 orang ibu nifas yang diwawancarai terdapat 2 orang ibu yang mengatakan ASI sudah keluar namun masih sedikit dan 4 orang ibu mengatakan ASI belum keluar. Berdasarkan permasalahan diatas, peneliti tertarik untuk melakukan sebuah penelitian yaitu pemberian ekstrak daun katuk pada ibu nifas yang memiliki bayi usia 0-6 bulan sehingga diharapkan dengan adanya penelitian ini dapat mengatasi permasalahan tersebut sehingga cakupan ASI Eksklusif dapat meningkat dalam rangka mendukung program pemerintah.

\section{METODOLOGI PENELITIAN}

Jenis penelitian yang digunakan adalah

Quasi Eksperimen menggunakan desain Non Equivalent Control Group Design yaitu kelompok pertama diberiken ekstrak daun katuk kemudian dilakukan post test sedangkan kelompok kedua tanpa perlakuan dan dilakukan post-test (Notoatmodjo, 2018). Penelitian dilaksanakan di Wilayah Kerja Puskesmas Kassi-Kassi Kota Makassar pada bulan Juli sampai dengan September 2020.
Sampel dalam penelitian ini adalah sebagian dari ibu nifas yang memiliki bayi berusia 0-6 bulan, sebanyak 30 orang, pengambilan sampel secara Purposive Sampling berdasarkan kriteria inklusi dan eksklusi yang ditetapkan oleh peneliti. Responden yang memenuhi kriteria akan diberikan dibagi dalam 2 kelompok yaitu kelompok intervensi dengan memberikan ekstrak daun katuk yang dikelola menggunakan standar CPOTB, SNI, dan ISO, sehingga dapat memberikan jaminan mutu dan rasa aman bagi responden. Kemudian ekstrak daun katuk ini 100\% bahan alami pilihan Sauropus androggynus $\mathrm{L}$ Merr folium terbaik dan telah memiliki BPOM. Tiap kapsul mengandung ekstrak yang setara dengan 2 gram simpilia Sauropus androgynous L. Meer folium. Dosis pemberian dalam bentuk kapsul dengan yaitu $2 \times 200 \mathrm{mg}$ untuk kelompok intervensi selama 15 hari dan akan dilihat efek pada hari ke 15 , sedangkan untuk kelompok control tidak diberikan perlakuan.

Instrumen penelitian yang digunakan yaitu lembar observasi dengan melihat seberapa sering bayi menyusu, terjadi pengosongan payudara atau tidak, posisi perlengkatan puting dengan mulut bayi, payudara kosong setelah bayi menyusu sampai kenyang dan tertidur, Frekuensi BAK minimal sebanyak 6 kali, Karakteristik BAK warna kuning jernih, frekuensi BAB 2-5x sehari. Analisis data yang digunakan yaitu analisis bivariat menggunakan independent t-test

\section{HASIL PENELITIAN \\ Karakteristik Responden}

Tabel 1

Distribusi Karakteristik Responden Ibu Berdasarkan Umur dan Paritas

\begin{tabular}{lcc}
\hline \multicolumn{1}{c}{ Variabel } & Frekuensi & $\%$ \\
\hline Umur & & \\
$<20$ & 1 & 3,33 \\
$20-35$ & 26 & 86,67 \\
$>35$ & 3 & 10 \\
Paritas & & \\
Primipara & 10 & 33,33 \\
Multipara & 20 & 66,67 \\
\hline Total & 30 & 100 \\
\hline \multicolumn{2}{c}{ *Sumber Data Primer, 2020 }
\end{tabular}

Berdasarkan tabel 1 menunjukkan bahwa dari 30 responden, ibu yang memiliki bayi usia $0-6$ bulan yang berumur $>35$ tahun sebanyak 3 responden $(10 \%), 20$ - 35 tahun sebanyak 26 responden $(86,67 \%)$, dan yang berumur $<20$ tahun 


\section{Rosdianah, Irmawati S}

sebanyak 1 responden (3,33\%). Kemudian dari 30 responden, ibu yang memiliki bayi usia 0-6 bulan yang multipara sebanyak 20 responden $(66,67 \%)$ dan yang primipara sebanyak 10 responden $(33,33 \%)$.

Tabel 2 menunjukkan bahwa dari 15 responden terdapat 11 responden $(73,33 \%)$ yang ASInya lancar dan 4 responden $(26,67 \%)$ yang ASInya tidak lancar.

Tabel 2.

Distribusi Frekuensi Kelompok Kontrol pada lbu yang Memiliki Bayi Usia 0-6 Bulan Tahun 2020

\begin{tabular}{ccc}
\hline Kelancaran ASI & Frekuensi & $\%$ \\
\hline Lancar & 11 & 73,33
\end{tabular}

\begin{tabular}{lcc} 
Tidak Lancar & 4 & 26,67 \\
\hline Total & 15 & 100 \\
\hline
\end{tabular}

Tabel 3 menunjukkan kelompok intervensi dari 15 responden 3 responden (20\%) yang ASInya lancar dan 12 responden (80\%) yang ASInya tidak lancar.

Tabel 3.

Distribusi Frekuensi Kelompok Intervensi pada Ibu yang Memiliki Bayi Usia 0-6 Bulan Tahun 2020

\begin{tabular}{l|c|c}
\hline \multicolumn{1}{c|}{ Kelancaran ASI } & Frekuensi & $\%$ \\
\hline Lancar & 3 & 20 \\
Tidak Lancar & 12 & 80 \\
\hline Total & 15 & 100 \\
\hline
\end{tabular}

\section{Analisis Bivariat}

Tabel 4.

Pengaruh pemberian ekstrak daun katuk terhadap kelancaran ASI

\begin{tabular}{cccccccc}
\hline \multirow{2}{*}{ Kelompok } & \multicolumn{4}{c}{ Kelancaran ASI } & \multicolumn{2}{c}{ Total } & \multirow{2}{*}{ Nilai } \\
\cline { 2 - 8 } & \multicolumn{2}{c}{ Lancar } & \multicolumn{2}{c}{ Tidak Lancar } & & & \\
\cline { 2 - 8 } & $\mathbf{n}$ & $\%$ & $\mathbf{n}$ & $\%$ & $\mathbf{N}$ & $\%$ & $\boldsymbol{\rho}$ \\
\hline Intervensi & 11 & 73,3 & 4 & 26,7 & 15 & 50 & \\
Kontrol & 4 & 6,1 & 11 & 73,3 & 15 & 50 & \multirow{2}{*}{0,009} \\
\hline Total & 15 & 50 & 15 & 50 & 33 & 100 & \\
\hline tindependent t-test & & & & & & &
\end{tabular}

Kemudian pada tabel 4 menggunakan uji independent sample $t$ test, didapatkan nilai $p$-value $0,009<a$ $(0,05)$, maka $\mathrm{H}_{0}$ ditolak dan $\mathrm{H}_{\mathrm{a}}$ diterima sehingga ada pengaruh pemberian ekstrak daun katuk terhadap kelancaran ASI pada ibu yang memiliki bayi usia 0-6 bulan di Wilayah Kerja Puskesmas Kassi-Kassi Kota Makassar Tahun 2020.

\section{PEMBAHASAN}

Berdasarkan hasil uji statistik menggunakan uji independent t-test pada tabel 4 untuk menilai pengaruh pemberian ekstrak daun katuk terhadap kelancaran ASI pada ibu nifas yang memiliki bayi usia 0-6 bulan diperoleh nilai signifikansi 0,009 itu berarti probabilitas $0,009<0,05$ maka Ho ditolak. Maka kesimpulannya ada pengaruh pemberian ekstrak daun katuk terhadap kelancaran ASI pada ibu nifas yang memiliki bayi usia 0-6 bulan. Asumsi peneliti ini disebabkan karena ibu mengkonsumsi makanan sehat dan seimbang seperti sayuran hijau. Daun katuk efektif dalam meningkatkan produksi ASI baik dibuat dalam bentuk sayuran maupun di lalap ini disebabkan karena kandungan alkolid dan sterol yang terdapat dalam daun katuk (Nindyaningrum, Rusmiyati and Purnomo, 2015; Aulianova, 2016). Berdasarkan hasil analisa diketahui bahwa pada tiap $100 \mathrm{~g}$ daun katuk mentah mengandung 59 kal., 4,8 g protein, $1 \mathrm{~g}$ lemak,
$11 \mathrm{~g}$ karbohidrat, $204 \mathrm{mg}$ kalsium, $83 \mathrm{mg}$ fosfor, 2,7 $\mathrm{mg}$ besi, $103.705 \mathrm{SI}$ vitamin $\mathrm{A}, 0,1 \mathrm{mg}$ vitamin $\mathrm{D}, 239$ $\mathrm{mg}$ vitamin $\mathrm{C}$ dan air $81 \mathrm{~g}$, sehingga dengan dosis yang telah ditetapkan sebanyak $400 \mathrm{mg} /$ hari dapat membantu ibu dalam mengatasi permasalahan produksi ASI (Annisa Namirah Nasution, 2018). Selain mengkonsumsi makanan sehat dan seimbang seperti sayuran hijau ditambah dengan mengkonsumsi ekstrak daun katuk sebanyak 2x200mg 15 hari dapat melancarkan ASI pada ibu disebabkan karena kandungan dari daun katuk yang mengandung protein, vitamin C, fosfor, kalsium, dan zat besi yang cukup tinggi, kemudian dengan kepatuhan ibu untuk memberikan ASI kepada bayinya secara on demand sehingga dengan adanya isapan bayi dapat merangsang hormone oksitosin dan prolactin untuk memproduksi ASI (Kent et al., 2006; Juliastuti, 2019; Aliya et al., 2020). 


\section{JKM (Jurnal Kebidanan Malahayati),Vol 7,No.2.April 2021, \\ ISSN (Print) 2476-8944 ISSN (Online) 2579-762X, Hal 265-271}

Ini sejalan dengan penelitian yang dilakukan oleh Sa'roni, dkk (2004) yang berjudul 'Effectiveness Of The Sauropus Androgynus (L.) Merr Leaf Extract In Increasing Mother's Breast Milk Production didapatkan bahwa pemberian ekstrak daun katuk pada kelompok ibu melahirkan dan menyusui bayinya dengan dosis $2 \times 300 \mathrm{mg} /$ hari selama 15 hari terus-menerus mulai hari ke 2 atau ke-3 setelah melahirkan dapat meningkatkan produksi ASI 50,7\% lebih banyak dibandingkan dengan kelompok ibu melahirkan dan menyusui bayinya yang tidak diberi ekstrak daun katuk. Dengan nilai $p(0,005)<a(0,05)$ sehingga adanya peningkatan volume ASI pada ibu yang telah melahirkan setelah diberikan ekstrak daun katuk (Sa'roni Sa'roni, Tonny Sadjiman, Mochammad Sja'bani, 2004). Dosis pemberian ekstrak daun katuk didasarkan pada penelitian efek farmakolgi ekstrak daun katuk yaitu $631,6 \mathrm{mg} / \mathrm{kg}$ berat badan yang setara dengan $900 \mathrm{mg} / \mathrm{hari}$ jika dosis tersebut diekstrapolasikan pada manusia berdasarkan luas permukaan tubuh dan kepekaan (Burger, 1966; Sa'roni Sa'roni, Tonny Sadjiman, Mochammad Sja'bani, 2004)

Hasil penelitian oleh Annisa Namira Nasution (2018) dengan memberikan ekstrak daun kelor dengan dosis $2 \times 1$ selama 2 minggu didapatkan perubahan nilai rata-rata pengukuran produksi ASI sebelum dan sesudah diberikan daun katuk yaitu 3258,3 menjadi 3595,8 dengan nilai sig (2 tailed) 0,021 sehingga disimpulkan bahwa ada efek pemberian simplisia daun katuk terhadap produksi ASI pada ibu post partum (Annisa Namirah Nasution, 2018).

Kemudian penelitian yang dilakukan oleh Rahmanisa Soraya dan Tara Aulianova (2016) didapatkan peningkatan produksi ASI pada ibu yang mengonsumsi ekstrak daun katuk yang mengandung alkaloid dan sterol (Aulianova, 2016).

Sehingga peneliti mengambil kesimpulan bahwa ekstrak daun katuk dapat memperlancar dan meningkatkan produksi ASI pada ibu menyusui ditambah dengan mengkonsumsi gizi yang cukup, frekuensi menyusui sesuai keinginan bayi, ketentraman jiwa dan pikiran.

\section{KESIMPULAN}

Berdasarkan hasil uji independent sample $t$ test didapatkan nilai $\mathrm{p}$-value $0,009<\mathrm{a}(0,05)$, maka $\mathrm{H}_{0}$ ditolak dan $\mathrm{H}_{\mathrm{a}}$ diterima. Hal ini menunjukkan bahwa ekstrak daun katuk memberikan pengaruh terhadap kelancaran pengeluaran ASI bagi ibu yang memiliki bayi usia 0-6 bulan di wilayah kerja Puskesmas Kassi - Kassi Kota Makassar Tahun 2020.

\section{SARAN}

Diharapkan kepada petugas kesehatan agar melakukan sosialisasi di masyarakat tentang efektifitas simplisia daun katuk terhadap produksi ASI pada bayi. Tenaga kesehatan perlu mengawasi ketepatan takaran/dosis, ketepatan waktu penggunaan, ketepatan cara penggunaan, dan ketepatan pemilihan bahan secara benar, sehingga menghasilkan obat tradisional berupa simplisia daun katuk.

\section{DAFTAR PUSTAKA}

Aliya, N. et al. (2020) 'Breast milk volume using portable double pump microcontroller Arduino Nano \&', Enfermería Clínica, 30, pp. 555-558. doi: 10.1016/j.enfcli.2019.07.159.

American Academy of Pediatrics (2012) 'Breastfeeding and the Use of Human Milk', Pediatrics, pp. 600-603. doi: 10.1542/peds.2011-3553.

Andreas, N. J., Kampmann, B. and Mehring Le-Doare, K. (2015) 'Human breast milk: A review on its composition and bioactivity', Early Human Development. doi: 10.1016/j.earlhumdev.2015.08.013.

Annisa Namirah Nasution (2018) Efektifitas Pemberian Simplisia Daun Katuk Terhadap Produksi Asi Pada Ibu Post Partum Di Praktik Mandiri Bidan Afriana. Politeknik Kementerian Kesehatan Medan.

Aulianova, R. S. dan T. (2016) 'Efektivitas Ekstraksi Alkaloid dan Sterol Daun Katuk (Sauropus androgynus) terhadap Produksi ASl', Jurnal Majority.

Ballard, O. and Morrow, A. L. (2013) 'Human Milk Composition. Nutrients and Bioactive Factors', Pediatric Clinics of North America, pp. 49-74. doi: 10.1016/j.pcl.2012.10.002.

Burger, A. (1966) 'Evaluation of Drug Activities: Pharmacometrics.', Journal of Medicinal Chemistry. doi: 10.1021/jm00321a067.

Dinas Kesehatan Kota Makassar (2019).

Fikawati, S. and Syafiq, A. (2009) 'Penyebab Keberhasilan dan Kegagalan Praktik Pemberian ASI Eksklusif', Kesmas: National Public Health Journal. doi: 10.21109/kesmas.v4i3.184.

Herawati, Y. and Desriyeni (2017) 'Kemas Ulang Informasi Manfaat Daun Katuk Untuk Produksi Air Susu Ibu (ASI)', Jurnal IImu Informasi 


\section{Rosdianah, Irmawati S}

Perpustakaan dan Kearsipan.

Hirani, S. A. A. and Karmaliani, R. (2013) 'The experiences of urban, professional women when combining breastfeeding with paid employment in Karachi, Pakistan: A qualitative study', Women and Birth. doi: 10.1016/j.wombi.2012.10.007.

Islamie, R. (2018) 'Uji Toksisitas Subkronis Singkat Oral Sup Daun Katuk (Sauropus androgynous) Pada Tikus Wistar Betina', Conference or Workshop Item (Paper). Available at: http://ikatanapotekerindonesia.net/uploads/rake rnasdocs/pit2018/kompilasi_abstrak_word_7_a pril_208_cover.pdf.

Jannah, A. M. (2016) 'Faktor-faktor yang Berhubungan dengan Perilaku Pemberian ASI Eksklusif pada Bayi Usia 6-12 Bulan di Kelurahan Gerem', Journal of Chemical Information and Modeling.

Juliastuti, J. (2019) 'EFEKTIVITAS DAUN KATUK (SAUROPUS ANDROGYNUS) TERHADAP KECUKUPAN ASI PADA IBU MENYUSUI DI PUSKESMAS KUTA BARO ACEH BESAR', Indonesian Journal for Health Sciences. doi: 10.24269/ijhs.v3i1.1600.

Kent, J. C. et al. (2006) 'Volume and frequency of breastfeedings and fat content of breast milk throughout the day', Pediatrics. doi: 10.1542/peds.2005-1417.

La Aga, E. and Alifariki, a O. (2019) 'CAKUPAN DAN DETERMINAN PEMBERIAN ASI EKSKLUSIF DI PEMUKIMAN KUMUH DALAM PERKOTAAN DI KECAMATAN TALLO KOTA MAKASSAR', Majalah Kesehatan. doi: 10.21776/ub.majalahkesehatan.006.01.5.

Mirzaie, P. et al. (2018) 'The effect of foot reflexology massage on breast milk volume of mothers with premature infants: A randomized controlled trial', European Journal of Integrative Medicine, 17(July 2017), pp. 72-78. doi: 10.1016/j.eujim.2017.11.010.

Nindyaningrum, Rusmiyati and Purnomo (2015) 'Pengaruh Pemberian Ekstrak Daun Katuk Terhadap Produksi ASI Pada lbu Post Partum', Jurnal IImu Keperawatan dan Kebidanan (JIKK).

Notoatmodjo (2018) 'Metodologi Penelitian Kesehatan. Jakarta: Rineka Cipta.', Notoatmodjo, S. (2018). Metodologi Penelitian Kesehatan. Jakarta:
Rineka Cipta.

Prabasiwi, A., Fikawati, S. and Syafiq, A. (2015) 'ASI Eksklusif dan Persepsi Ketidakcukupan ASl', Kesmas: National Public Health Journal. doi: 10.21109/kesmas.v9i3.691.

Rahmanisa, S. and Aulianova, T. (2016) 'Efektivitas Ekstraksi Alkaloid dan Sterol Daun Katuk (Sauropus androgynus) terhadap Produksi ASIBNPB. (2020). Bencana Indonesia 2020. https://bnpb.go.id/infografis/infografis-bencanaindonesia-2020', Jurnal Majority.

Riset Kesehatan Dasar. 2018. KEMENKES

S, W., M, D. E. and E., L. W. (2012) 'Uji Teratogenik Infusa Daun Katuk Pada Mencit Hamil', Warta Tumbuhan Obat Indonesia, 3(3). Available at: http://ejournal.litbang.depkes.go.id/index.php/wt oi.

Sa'roni Sa'roni, Tonny Sadjiman, Mochammad Sja'bani, Z. Z. (2004) 'Effectiveness Of The Sauropus Androgynus (L.) Merr Leaf Extract In Increasing Mother's Breast Milk Production', Media of Health Research and Development, 14(3). Available at: http://ejournal.litbang.kemkes.go.id/index.php/M PK/article/view/903.

Saskiyanto Manggabarani, Anto Jamma Hadi, I. S. and Bunga, S. (2018) 'HUBUNGAN PENGETAHUAN , STATUS GIZI , POLA MAKAN , PANTANGAN MAKANAN DENGAN KELANCARAN PRODUKSI ASI PADA IBU MENYUSUI', Journal of The World of Nutrition, 1(1), pp. 1-9. Available at: https://www.researchgate.net/publication/32921 5380_Hubungan_Status_Gizi_Pola_Makan_Pa ntangan_Makanan_dengan_Kelancaran_Produ ksi_ASI_Pada_lbu_Menyusui_di_Kota_Makass ar/fulltext/5bfd57d4a6fdcc35428b993f/Hubunga n-Status-Gizi-Pola-Makan-PantanganMakanan-deng.

Subratha, H. F. A. (2020) 'Determinan Kegagalan Pemberian Asi Eksklusif Pada lbu Rumah Tangga Di Kecamatan Marga', Jurnal Medika Usada, 3(1), pp. 61-72.

Suryaningsih, M. (2009) 'Gambaran Produksi ASI antara Ibu yang Mengonsumsi Daun Katuk dan Tidak Mengonsumsi Daun Katuk.', Jurnal IImiah IImu Kebidanan dan Kandungan, 2(2). 
JKM (Jurnal Kebidanan Malahayati),Vol 7,No.2.April 2021,

ISSN (Print) 2476-8944 ISSN (Online) 2579-762X, Hal 265-271

Suwanti, E. and Kuswati (2016) 'Pengaruh Konsumsi Ekstrak Daun Katuk Terhadap Kecukupan ASI Pada Ibu Menyusui Di Klaten', Jurnal Terpadu IImu Kesehatan, 5(2), pp. 110-237.

Suwanti, E. and Kuswati, K. (2016) 'Pengaruh Konsumsi Ekstrak Daun Katuk Terhadap Kecukupan ASI Pada Ibu Menyusui Di Klaten', Interest: Jurnal IImu Kesehatan. doi: 10.37341/interest.v5i2.42.

Tri Mulyani, Y. W. et al. (2017) 'EKSTRAK DAUN KATUK (Sauropus androgynus (L) Merr) SEBAGAI ANTIBAKTERI TERHADAP Propionibacterium acnes dan Staphylococcus epidermidis', JFL: Jurnal Farmasi Lampung. doi: 10.37090/jfl.v6i2.21.

WHO (2017) 'Maternal, newborn, child and adolescent health', Global strategy for infant and young child feeding. 